T. 2, № 1, 2020

УДК 621.311:620.97

Ю. О. Білецький

Національний університет “Львівська політехніка", кафедра електроприводу і комп’ютеризованих електромеханічних систем, yurii.o.biletskyi@lpnu.ua

P.-I. В. Кузик

Національний університет “Львівська політехніка”, кафедра електроприводу і комп'ютеризованих електромеханічних систем,

kyzukrostuk@gmail.com

Ю. В. Ломпарт

Національний університет “Львівська політехніка”, кафедра електроприводу і комп’ютеризованих електромеханічних систем, lompartyurii@gmail.com

\title{
СИНТЕЗ ТА АНАЛІЗ СИСТЕМИ ЕНЕРГОФОРМУЮЧОГО КЕРУВАННЯ ВІТРОСОНЯЧНОЮ ЕНЕРГОУСТАНОВКОЮ З ГІБРИДНОЮ СИСТЕМОЮ НАКОПИЧЕНЯ ЕНЕРГІЇ
}

https://doi.org/10.23939/sepes2020.01.008

(С Білеиький Ю. О., Кузик Р.-І. В., Ломпарт Ю. В., 2020

Однісю з основних задач сьогодення є розвиток альтернативної енергетики. Попри значну кількість переваг такі джерела енергії, як сонце та вітер, не с постійними, а оскільки ці джерела природно працюють у «протифазі», то їх доцільно використовувати разом. Також зважаючи на їх непостійність, зазвичай 3 ними використовують різні накопичувальні системи, зокрема гібридні системи накопичення, такі як посднання акумуляторної батареї та суперконденсатора, що мають кращі експлуатаційні характеристики. Отже, об'єкт вітросонячної енергоустановки є складною системою, яка потребус особливого підходу до керування. Одними 3 відомих підходів до побудови систем керування складними об'сктами с енергетичні підходи.

Показано процедуру синтезу універсальної системи енергоформуючого керування вітросонячною енергоустановкою 3 гібридною системою накопичення 3 широкими можливостями для налаштування. Використання різних параметрів системи енергоформуючого керування, що відображає введення додаткових взаємозв'язків та демпфування, дає можливість скорегувати перетікання енергії в середині замкненої системи, а отже, здійснити налаштування залежно від бажаного результату. Наприклад, підтримання напруги, яка прикладається до навантаження на одному рівні або плавність перехідних процесів струму через акумуляторну батарею. Проаналізовано вплив можливих параметрів та їх посднання на роботу замкненої системи. Синтезовано чотири найефективніші структури системи енергоформуючого керування 3 різними 
конфігураціями параметрів: 3 природним перетіканням енергії, 3 введенням додаткових взаємозв'язків та демпфування в підсистеми накопичення, з веденням взаємозв'язків у підсистеми генерації, а також в обидва типи підсистем. Проведено порівняльні дослідження, в результаті яких підтверджено доцільність введення додаткових взаємозв'язків до всіх підсистем, а саме: сонячної енергоустановки, вітроенергоустановки, акумуляторної батареї та суперконденсатора. Така система має змогу забезпечити оптимальне керування як відбором енергії від усіх джерел, так і її розподілом по накопичувачах енергії.

Системи енергоформуючого керування вітросонячною енергоустановкою завдяки введенню додаткових взасмозв'язків та демпфування, надають широких можливостей для налаштування. Це особливо корисно у таких складних системах, як вітросонячні енергоустановки 3 гібридними системами накопичення, де потрібно узгоджувати роботу підсистем з урахуванням багатьох вимог.

Ключові слова: системи керування, енергетичні підходи, енергоформуюче керування, вітроенергоустановка, сонячна енергоустановка, гібридна система накопичення енергії

\section{Вступ}

Сучасний розвиток науково-технічного прогресу ставить завдання пошуку ефективних джерел енергії для забезпечення потреб людства з врахуванням екологічності їхнього використання [1]. Серед екологічних джерел енергії, що їх називають альтернативними джерелами енергії або поновлювальними джерелами енергії, одними з найпопулярніших $є$ сонячна енергетика, джерелом енергії якої $\epsilon$ сонячна радіація та вітрова, джерелом енергії якої є сила вітру [2]. Однак, одним з головних недоліків як сонячних так і вітрових енергоустановок $\epsilon$ те, що генерація електроенергії від цих джерел не $\epsilon$ постійною. Цей аспект зумовлює доцільність використання сонячної та вітрової енергоустановок разом. Виходячи 3 досліджень, які показують закономірності чергування інтенсивності даних джерел [3], це стабілізує сумарну генерацію енергії та збільшує шанси на те, що енергії відібраної від спільної роботи цих джерел буде достатньо для забезпечення потреб споживача.

Ще однією проблемою, що обмежують швидке впровадження систем генерації електроенергії на основі поновлюваних джерел, таких як вітрова та сонячна енергія, зокрема автономних, є висока вартість систем накопичення та їх термін служби. 3 метою зменшення собівартості та збільшення терміну експлуатації використовують різного роду гібридні системи [4]. Одним з основних компонентів високої вартості $\epsilon$ акумуляторні батареї, які використовуються для зберігання електроенергії. Суперконденсатори мають набагато вищу питому потужність, тому в них $є$ потенціал, щоб доповнювати традиційні системи батарей. Використання суперконденсаторів також знижує струмові навантаження на системи батарей, суттєво збільшуючи період життя батареї [5]. Їх поєднання в основному розглядають в автомобільній промисловості для гібридного та електричного транспорту через зменшення розміру загальної системи накопичення енергії, однак завдяки своїм енергетичним перевагам останнім часом застосовують і у системах генерації електроенергії.

Використання вітросонячної енергоустановки з гібридною системою накопичення, що являє собою складну систему, яка поєднує низку підсистем, створює потребу у правильному і ефективному керуванні цією системою.

Аналіз попередніх досліджень та публікацій

Хоча енергетичні підходи до керування відомі вже давно, їхнє застосування до побудови систем керування та детальне дослідження розпочалися недавно. Такі підходи можна застосовувати до будь-яких систем, оскільки енергія, яка є основою цих підходів, є невід'ємною частиною усіх систем - i механічних, i хімічних, і електротехнічних. Ці підходи почали застосовувати і при керуванні енергоустановками альтернативної енергетики (такими, як вітроенергетика та сонячна енергетика), гібридного та електричного транспорту в поєднанні 3 гібридними системи накопичення електроенергії [2-7]. 
Енергетичні підходи базуються на фізичних законах і належать до фізичної теорії автоматичного керування [6]. Основним рівнянням для одного з енергетичних підходів - енергоформуючого керування - $€$ функція повної енергії (Гамільтоніан), що має вигляд [7]:

$$
H(\boldsymbol{x})=\frac{1}{2} \boldsymbol{x}^{m} \boldsymbol{D} \boldsymbol{x}
$$

де $H(\boldsymbol{x})$ - функція повної енергії; $\boldsymbol{x}$ - вектор станів; D - діагональна матриця коефіцієнтів інерційності системи.

Ціллю енергоформуючого керування буде забезпечення роботи системи у точці бажаної рівноваги $\boldsymbol{x}_{0}$, яка визначається сигналом завдання. Цього досягають за рівнянням [8]:

$$
H_{d}(\boldsymbol{x})=H(\boldsymbol{x})+H_{a}(\boldsymbol{x})
$$

де $H_{\mathrm{a}}(\boldsymbol{x})$ - корегувальна функція енергії системи керування.

Для зручності роботи з енергетичними підходами система розглядається як Гамільтонова 3 керованими портами (входами та виходами) [9]:

$$
\left\{\begin{array}{l}
\dot{\boldsymbol{x}}(t)=[\boldsymbol{J}(\boldsymbol{x})-\boldsymbol{R}(\boldsymbol{x})] \frac{\partial H}{\partial \boldsymbol{x}}+\boldsymbol{G}(\boldsymbol{x}) \cdot \boldsymbol{u}(t) \\
\boldsymbol{y}(t)=\boldsymbol{G}^{m}(\boldsymbol{x}) \frac{\partial H}{\partial \boldsymbol{x}}
\end{array}\right.
$$

де $\boldsymbol{J}(\boldsymbol{x})$ - кососиметрична матриця, що описує взаємозв' язки в системі; $\boldsymbol{R}(\boldsymbol{x})$ - симетрична матриця, що описує демпфування в системі; $\boldsymbol{G}(\boldsymbol{x})$ - матриця портів; $\boldsymbol{u}(\boldsymbol{x})$ - вектор керуючих впливів; $\boldsymbol{y}(\boldsymbol{x})-$ вектор вихідних енергетичних змінних.

Процес синтезу системи енергоформуючого керування починається 3 того, що математичну модель об'єкта керування, яку зазвичай зображують за допомогою диференційних та алгебраїчних рівнянь, зводять до вигляду (3), тобто формують вектори та матриці [10].

Наступним кроком прирівнюється рівняння бажаної системи із введеними додатковими взаємозв' язками та демпфуваннями до рівняння системи згідно з математичною моделлю об' єкта [6]:

$$
\dot{\boldsymbol{x}}(t)=[\boldsymbol{J}(\boldsymbol{x})-\boldsymbol{R}(\boldsymbol{x})] \frac{\partial H}{\partial \boldsymbol{x}}+\boldsymbol{G}(\boldsymbol{x}) \cdot \boldsymbol{u}(t)=\left[\boldsymbol{J}_{d}(\boldsymbol{x})-\boldsymbol{R}_{d}(\boldsymbol{x})\right] \boldsymbol{D}\left(\boldsymbol{x}-\boldsymbol{x}_{0}\right)
$$

\section{Постановка задачі}

Отже, завданням пропонованих у статті досліджень $є$ синтез системи енергоформуючого керування вітросонячної енергоустановки з гібридними системами накопичення енергії, аналіз та порівняння впливу використання різних конфігурацій регуляторів на роботу синтезованої системи шляхом комп'ютерного моделювання за допомогою засобів MATLAB (Simulink).

\section{Виклад основного матеріалу}

Базуючись на джерелах [10-14] складемо принципову електричну схему вітросонячної енергоустановки з гібридними системами накопичення енергії (рис. 1) та їі математичну модель:

$$
\left\{\begin{array}{c}
L_{b} \frac{d i_{b}}{d t}=U_{b}-U_{d c}\left(1-\gamma_{b}\right) \\
L_{s c} \frac{d i_{s c}}{d t}=U_{s c}-U_{d c}\left(1-\gamma_{s c}\right) \\
C \frac{d U_{d c}}{d t}=i_{b}\left(1-\gamma_{b}\right)+i_{s c}\left(1-\gamma_{s c}\right)+i_{p v}\left(1-\gamma_{p v}\right)+i_{w}\left(1-\gamma_{w}\right)-i_{l} \\
C_{s c} \frac{d U_{s c}}{d t}=-i_{s c} \\
L_{l} \frac{d i_{l}}{d t}=U_{d c}-E_{l}-R_{l} i_{l} \\
L_{p v} \frac{d i_{p v}}{d t}=U_{p v}-U_{d c}\left(1-\gamma_{p v}\right) \\
L_{w} \frac{d i_{w}}{d t}=U_{w}-U_{d c}\left(1-\gamma_{w}\right)
\end{array}\right.
$$

де $L_{\mathrm{b}}, L_{\mathrm{sc}}, L_{\mathrm{l}}, L_{\mathrm{pv}}, L_{\mathrm{w}}$ - індуктивності в колах акумуляторної баратеї, суперкондансатора, навантаження, сонячної енергоустановки та вітроустановки відповідно; $R_{1}$ - активний опір 
навантаження; $E_{1}$ - проти ЕРC навантаження; $\gamma_{\mathrm{b}}, \gamma_{\mathrm{sc}}, \gamma_{\mathrm{pv}}, \gamma_{\mathrm{w}}$ - коефіцієнти заповнення імпульсів DC$\mathrm{DC}$ перетворювачів до відповідних електричних кіл (за аналогією до індуктивностей); $U_{\mathrm{dc}}-$ напруга, що подається на навантаження.

Вітросонячна енергоустановка складається з сонячної (СЕУ) та вітрової (ВЕУ) енергоустановок, що через DC/DC перетворювачі передають енергію на шину постійного струму, до якої, своєю чергою, під'єднані навантаження (Load), та гібридної системи накопичення енергії, що містить акумуляторну батарею та суперконденсатор, що під’єднано до шини постійного струму через відповідні DC/DC перетворювачі.

Рис. 1. Принципова електрична схема вітросонячної енергоустановки з гібридними системами накопичення енергіi

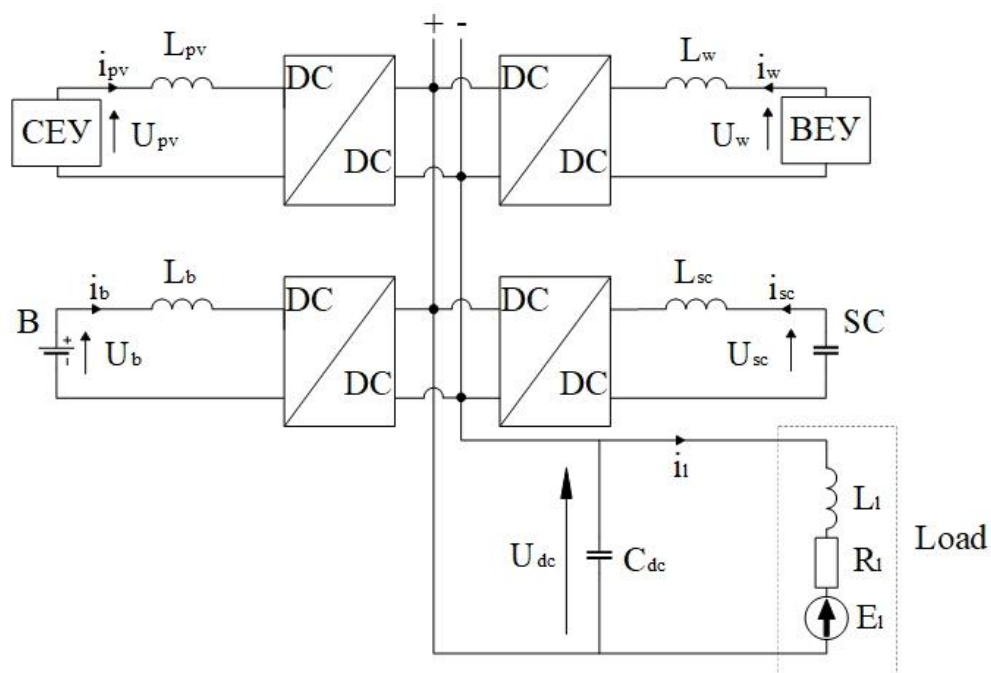

Оскільки накопичувачами енергії в такій системі $є$ індуктивності в колах навантаження, СЕУ, ВЕУ, акумуляторної батареї та суперконденсатора, а також ємності суперконденсатора та конденсатора гини постійного струму, то вектори стану, вхідних і вихідних координат вибираємо так [15]:

$$
\boldsymbol{x}=\left[\begin{array}{l}
x_{1} \\
x_{2} \\
x_{3} \\
x_{4} \\
x_{5} \\
x_{6} \\
x_{7}
\end{array}\right]=\left[\begin{array}{c}
L_{b} i_{b} \\
L_{s c} i_{s c} \\
C v_{d c} \\
C_{s c} v_{s c} \\
L_{l} i_{l} \\
L_{p v} i_{p v} \\
L_{w} i_{w}
\end{array}\right]=\boldsymbol{D}\left[\begin{array}{c}
i_{b} \\
i_{s c} \\
v_{d c} \\
v_{s c} \\
i_{l} \\
i_{p v} \\
i_{w}
\end{array}\right] ; u=\left[\begin{array}{c}
V_{b} \\
0 \\
0 \\
0 \\
-E_{l} \\
V_{p v} \\
V_{w}
\end{array}\right] ; y=\left[\begin{array}{c}
i_{b} \\
i_{s c} \\
v_{d c} \\
v_{s c} \\
i_{l} \\
i_{p v} \\
i_{w}
\end{array}\right] ; \boldsymbol{G}=\left[\begin{array}{ccccccc}
1 & 0 & 0 & 0 & 0 & 0 & 0 \\
0 & 1 & 0 & 0 & 0 & 0 & 0 \\
0 & 0 & 1 & 0 & 0 & 0 & 0 \\
0 & 0 & 0 & 1 & 0 & 0 & 0 \\
0 & 0 & 0 & 0 & 1 & 0 & 0 \\
0 & 0 & 0 & 0 & 0 & 1 & 0 \\
0 & 0 & 0 & 0 & 0 & 0 & 1
\end{array}\right]
$$

де $x_{1} \ldots x_{7}$ - елементи вектора стану; $D=\operatorname{diag}\left[\begin{array}{lllllll}L_{\mathrm{b}} & L_{\mathrm{sc}} & C & C_{\mathrm{sc}} & L_{1} & L_{\mathrm{pv}} & L_{\mathrm{w}}\end{array}\right]$ - діагональна матриця інерційностей системи.

Виходячи з обраного вектору стану $\boldsymbol{x}$ та згідно з (1), Гамільтоніан системи набуде вигляду:

$$
\mathrm{H}(\mathrm{x})=\frac{1}{2} \mathrm{x}^{\mathrm{T}} \mathrm{Dx}=\frac{1}{2}\left(\frac{1}{\mathrm{~L}_{\mathrm{b}}} \mathrm{x}_{1}^{2}+\frac{1}{\mathrm{~L}_{\mathrm{sc}}} \mathrm{x}_{2}^{2}+\frac{1}{\mathrm{C}} \mathrm{x}_{3}^{2}+\frac{1}{\mathrm{C}_{\mathrm{sc}}} \mathrm{x}_{4}^{2}+\frac{1}{1} \mathrm{x}_{5}^{2}+\frac{1}{\mathrm{~L}_{\mathrm{pv}}} \mathrm{x}_{6}^{2}+\frac{1}{\mathrm{~L}_{\mathrm{w}}} \mathrm{x}_{7}^{2}+\right)
$$

Тоді матриця взаємозв'язків установки у формі гамільтонової системи з керованими портами набуде вигляду:

$$
\boldsymbol{J}(\boldsymbol{x})=\left[\begin{array}{ccccccc}
0 & 0 & -\left(1-\gamma_{b}\right) & 0 & 0 & 0 & 0 \\
0 & 0 & -\left(1-\gamma_{s c}\right) & 1 & 0 & 0 & 0 \\
\left(1-\gamma_{b}\right) & \left(1-\gamma_{s c}\right) & 0 & 0 & -1 & \left(1-\gamma_{p v}\right) & \left(1-\gamma_{w}\right) \\
0 & -1 & 0 & 0 & 0 & 0 & 0 \\
0 & 0 & 1 & 0 & 0 & 0 & 0 \\
0 & 0 & -\left(1-\gamma_{p v}\right) & 0 & 0 & 0 & 0 \\
0 & 0 & -\left(1-\gamma_{w}\right) & 0 & 0 & 0 & 0
\end{array}\right]
$$


Матриця демпфувань $\boldsymbol{R}(\boldsymbol{x})$ системи матиме лише один ненульовий елемент, а саме $-\boldsymbol{R}_{55}(\boldsymbol{x})=R_{1}$.

Для керування шляхом формування бажаних взаємозв'язків та демпфування задаємось універсальною структурою матриць системи керування $\boldsymbol{J}_{\mathrm{a}}(\boldsymbol{x})$ та $\boldsymbol{R}_{\mathrm{a}}(\boldsymbol{x})$ :

$$
\begin{array}{r}
J_{a}(x)=\left[\begin{array}{ccccccc}
0 & j_{12} & j_{13} & j_{14} & j_{15} & j_{16} & j_{17} \\
-j_{12} & 0 & j_{23} & j_{24} & j_{25} & j_{26} & j_{27} \\
-j_{13} & -j_{23} & 0 & j_{34} & j_{35} & j_{36} & j_{37} \\
-j_{14} & -j_{24} & -j_{34} & 0 & j_{45} & j_{46} & j_{47} \\
-j_{15} & -j_{25} & -j_{35} & -j_{45} & 0 & j_{56} & j_{57} \\
-j_{16} & -j_{26} & -j_{36} & -j_{46} & -j_{56} & 0 & j_{67} \\
-j_{17} & -j_{27} & -j_{37} & -j_{47} & -j_{57} & -j_{67} & 0
\end{array}\right] \\
\boldsymbol{R}_{a}(\boldsymbol{x})=\left[\begin{array}{ccccccc}
-r_{11} & 0 & 0 & 0 & 0 & 0 & 0 \\
0 & -r_{22} & 0 & 0 & 0 & 0 & 0 \\
0 & 0 & -r_{33} & 0 & 0 & 0 & 0 \\
0 & 0 & 0 & -r_{44} & 0 & 0 & 0 \\
0 & 0 & 0 & 0 & -r_{55} & 0 & 0 \\
0 & 0 & 0 & 0 & 0 & -r_{66} & 0 \\
0 & 0 & 0 & 0 & 0 & 0 & -r_{77}
\end{array}\right]
\end{array}
$$

Підставивши матриці та вектори в рівняння (4), за допомогою розробленої програми в Mathcad, синтезуємо рівняння регуляторів, що формують сигнали керування чотирма DC-DC перетворювачами системи. Оскільки є 28 можливих параметрів регуляторів універсальної системи енергоформуючого керування, що суттєво ускладнює процедуру ії налаштування, було прийнято рішення попередньо дослідити вплив кожного параметра на поведінку системи, а також їх взаємовпливів заданням інших параметрів нульовими і повторення процедури синтезу розробленою програмою. В результаті попередніх досліджень було виявлено чотири найефективніші системи керування, із різними комбінаціями додатково введених взаємозв'язків та демпфувань. Рівняння регуляторів відповідних систем наведено в таблиці.

3 метою проведення порівняльних досліджень синтезованих систем, відповідно до принципової схеми (рис. 1) складено комп'ютерну модель (рис. 2), де зовнішні впливи моделюються джерелами змінної напруги $(E(l o a d), U(w), U(p v))$, a DC-DC перетворювачі використано 3 внутрішньої бібліотеки MATLAB.

3 метою спрощення $U(w), U(p v))$ моделюються джерелами напруги, приймаючи, що вітрова та сонячна електроустановки містять контролери і не видають напругу, пропорційну до відібраної потужності. В подальших дослідженнях вони будуть змінені на моделі бібліотек MATLAB.

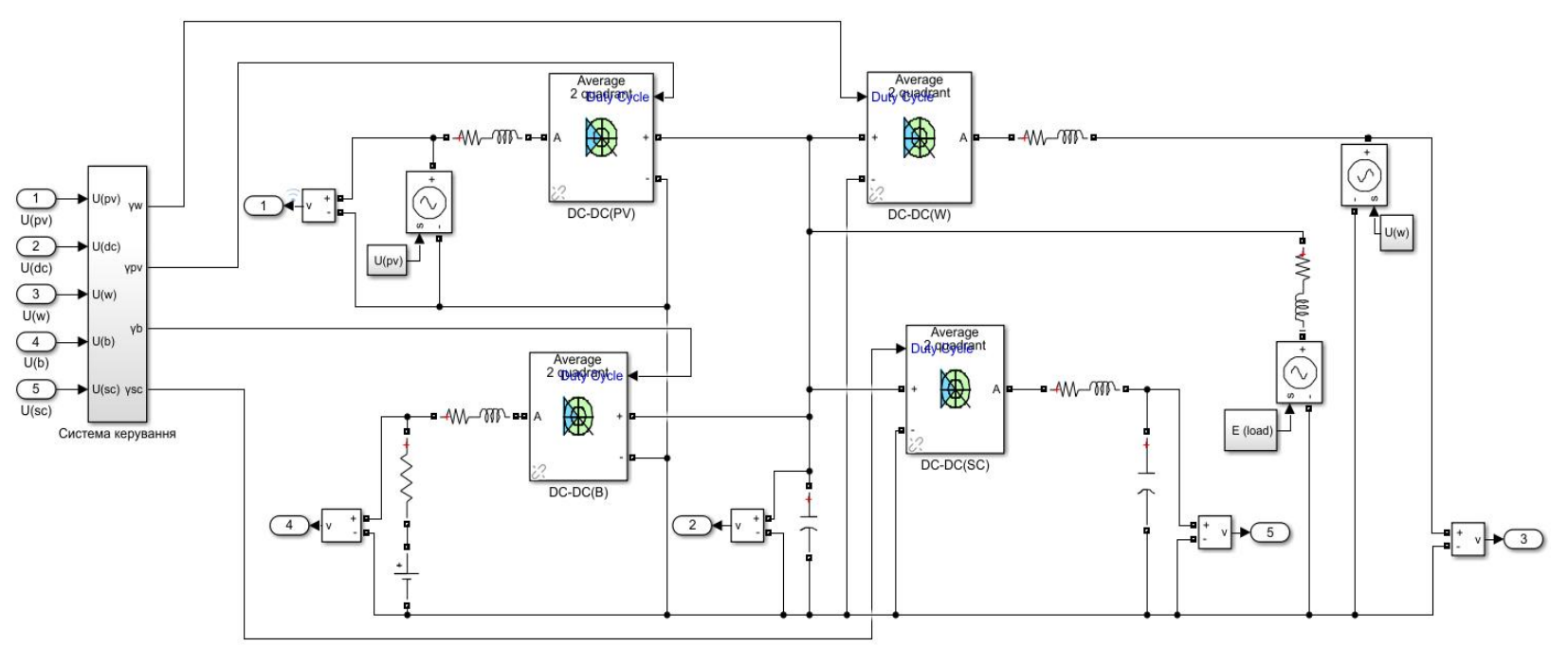

Рис. 2. Комп'ютерна досліджуваної вітросонячної енергоустановки з гібридними системами накопичення енергї 
Дослідження проводились за наступних параметрів досліджуваної установки: $L_{\mathrm{b}}=L_{\mathrm{l}}=0,001$ Гн, $L_{\mathrm{sc}}=0,0005 \Gamma \mathrm{H}, L_{\mathrm{pv}}=L_{\mathrm{w}}=0,003 \Gamma \mathrm{H}, C=0,01 \Phi$ та $C_{\mathrm{sc}}=45 \Phi$. Регулятори систем керування були налаштовані наступним чином: 3 нульовими налаштуваннями (Система 1$), j_{13}=0,7, j_{23}=0,5$, $r_{22}=0.005$ (Система 2), $j_{14}=0,2, j_{24}=0.15, j_{36}=0.5, j_{37}=0,7$ (Система 3) та $j_{46}=0,5, j_{47}=0,2$ (Система 4). Сигнали завдання було сформовано як: $U_{\mathrm{b} 0}=24 \mathrm{~B}, U_{\mathrm{dc} 0}=48 \mathrm{~B}$ та $U_{\mathrm{sc} 0}=30 \mathrm{~B}$.

\section{Коефіцієнти заповнення імпульсів}

\begin{tabular}{|c|c|c|}
\hline & Система 1 & Система $2\left(j_{13} ; j_{23} ; r_{22}\right)$ \\
\hline$\gamma_{b}$ & $-\frac{U_{b}-U_{d c 0}}{U_{d c 0}}$ & $-\frac{U_{b}-U_{d c 0}-U_{d c} j_{13}+U_{d c 0} j_{13}}{U_{d c 0}}$ \\
\hline$\gamma_{s c}$ & $\frac{U_{d c 0}-U_{s c 0}}{U_{d c 0}}$ & $\frac{U_{d c 0}-U_{s c 0}+U_{d c} j_{23}-U_{d c 0} j_{23}+i_{s c} r_{22}}{U_{d c 0}}$ \\
\hline$\gamma_{p v}$ & $-\frac{U_{p v}-U_{d c 0}}{U_{d c 0}}$ & $-\frac{U_{p v}-U_{d c 0}}{U_{d c 0}}$ \\
\hline$\gamma_{w}$ & $-\frac{U_{w}-U_{d c 0}}{U_{d c 0}}$ & $-\frac{U_{w}-U_{d c 0}}{U_{d c 0}}$ \\
\hline & Система $3\left(j_{14} ; j_{24} ; j_{36} ; j_{37}\right)$ & Система $4\left(j_{46} ; j_{47}\right)$ \\
\hline$\gamma_{b}$ & $-\frac{U_{b}-U_{d c 0}-U_{s c} j_{14}+U_{s c 0} j_{14}}{U_{d c 0}}$ & $-\frac{U_{b}-U_{d c 0}}{U_{d c 0}}$ \\
\hline$\gamma_{s c}$ & $\frac{U_{d c 0}-U_{s c 0}+U_{s c} j_{24}-U_{s c 0} j_{24}}{U_{d c 0}}$ & $\frac{U_{d c 0}-U_{s c 0}}{U_{d c 0}}$ \\
\hline$\gamma_{p v}$ & $-\frac{U_{p v}-U_{d c 0}+U_{d c} j_{36}-U_{d c 0} j_{36}}{U_{d c 0}}$ & $-\frac{U_{p v}-U_{d c 0}+U_{s c} j_{46}-U_{s c 0} j_{46}}{U_{d c 0}}$ \\
\hline$\gamma_{w}$ & $-\frac{U_{w}-U_{d c 0}+U_{d c} j_{37}-U_{d c 0} j_{37}}{U_{d c 0}}$ & $-\frac{U_{w}-U_{d c 0}+U_{s c} j_{47}-U_{s c 0} j_{47}}{U_{d c 0}}$ \\
\hline
\end{tabular}

На систему діє три зовнішні впливи: це напруга від сонячної панелі (рис. 3), напруга від вітроенергоустановки (рис. 4) та проти ЕРС навантаження (рис. 5); сигнали завдання сформовано так, щоб можна було оцінити вплив кожного з них як окремо, так і в комплексі, що дає можливість дослідити роботу системи та відпрацювання сигналів завдання САК за різних режимів роботи.

У результаті досліджень було виявлено такі впливи параметрів регуляторів та наведено відповідні рекомендації по їх застосуванню:

$j_{13}$ - впливає на форсування протікання перехідних процесів струму акумуляторної батареї, він корисний для підтримки напруги $U_{\mathrm{dc}}$ на бажаному рівні, однак не забезпечує плавності протікання перехідних процесів струму батареї.

$j_{23}$ - згладжує перехідній процес струму через акумуляторну батарею та форсує перехідні процеси струму через суперконденсатор.

$r_{22}$ - підтримує напругу $U_{\mathrm{dc}}$ на заданому рівні та не допускає просадки при зміні навантаження. 


\section{Ю. О. Білецький, Р.-І. В. Кузик Ю. В., Ломпарт}

$j_{14}$ - стабілізує напругу $U_{\mathrm{dc}}$ на бажаному рівні, збільшує та підтримує на певному рівні струм через акумуляторну батарею та навантаження. Збільшує усталене значення напруги суперконденсатора та, своєю чергою, зменшує його на акумуляторній батареї.

$j_{24}$ - стабілізує напругу $U_{\mathrm{dc}}$ в околі заданого рівня, суттєво зменшує напругу на суперконденсаторі та стабілізує струм через акумуляторну батарею та на навантаженні.

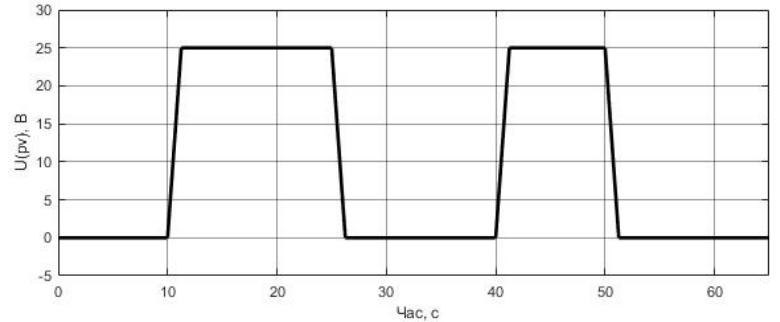

Рис. 3. Напруга на сонячній панелі

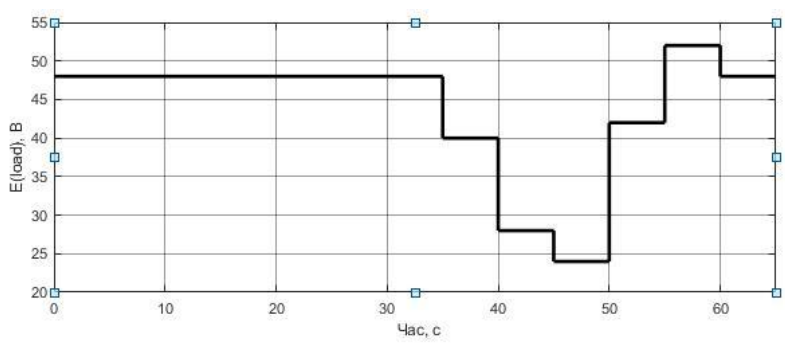

Рис. 5. Проти ЕРС навантаження



Рис. 7. Напруга через суперконденсатор

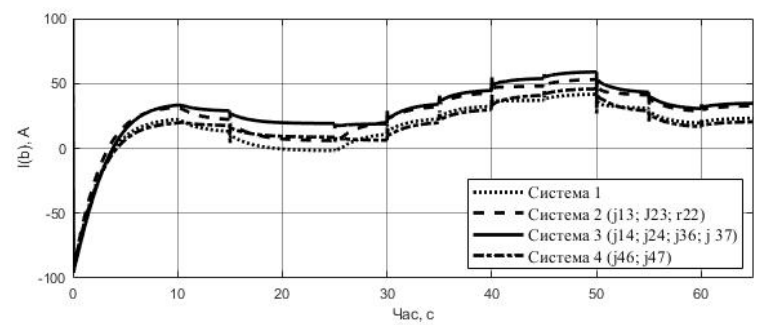

Рис. 9. Струм через акумуляторну батарею

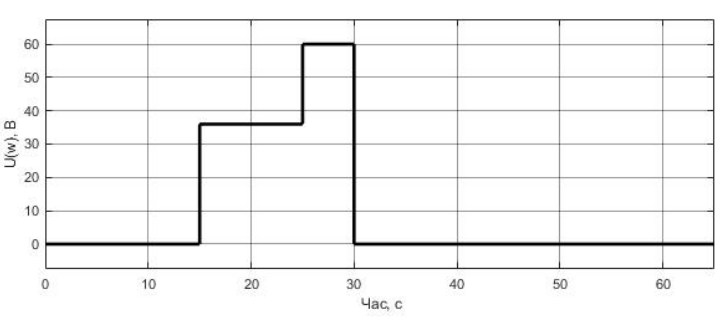

Рис. 4. Напруга на вітроенергоустановиі

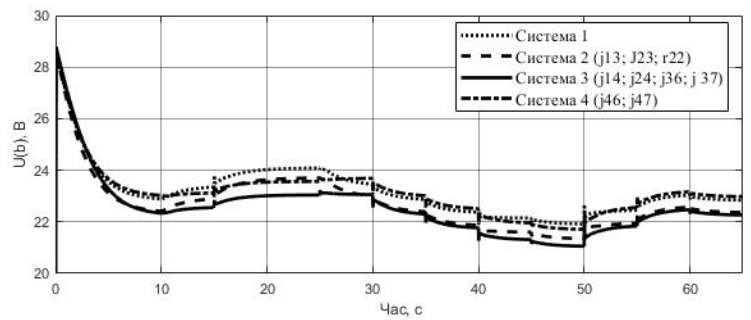

Pис. 6. Напруга на батареї

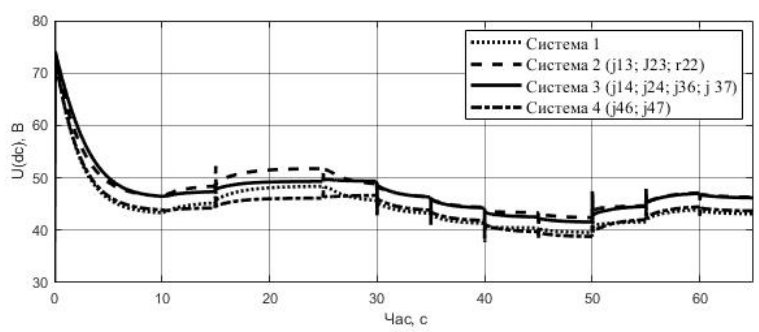

Рис. 8. Напруга на навантаженні



Рис. 10. Струм через суперконденсатор



Рис. 11. Струм через навантаження 
Синтез та аналіз системи енергоформуючого керування вітросонячною енергоустановкою...

$j_{36}$ - коефіцієнт підтримує напругу $U_{\mathrm{dc}}$ на заданому рівні, зменшує напругу на суперконденсаторі в зоні дії напруги від сонячної енергоустановки, стабілізує струм через акумуляторну батарею та навантаження.

$j_{37}$ - коефіцієнт стабілізує напругу $U_{\mathrm{dc}}$ а також згладжує перехідні процеси струму через акумуляторну батарею та навантаження.

$j_{46}$ - даний коефіцієнт стабілізує струм через акумуляторну батарею на ділянці дії збурення 3 сонячної енергоустановки, стабілізує напругу $U_{\mathrm{dc}}$ та стрибки струму через навантаження.

$j_{47}$ - дослідження показали, що коефіцієнт стабілізує напругу $U_{\mathrm{dc}}$ в зоні дії збурення 3 вітроенергоустановки, дещо зменшує напругу на акумуляторній батареї та суперконденсаторі, стабілізує струм через батарею та навантаження.

Отже, використання різних параметрів дає можливість скорегувати перетікання енергії в середині системи, а отже, здійснити налаштування залежно від бажаного результату. Прикладом вищесказаного можуть бути необхідність підтримання напруги, яка прикладається до навантаження на одному рівні, або плавність перехідних процесів струму через акумуляторну батарею. Так, Система 1 немає додатково введених взаємозв'язків та демпфувань, що виключає необхідність у налаштуванні, а перетікання енергій відбувається природним чином. Система 2 завдяки додатково введеними взаємозв'язкам та демпфуванню покращує перетікання енергії в гібридних системах накопичення енергії. В Системі 4 відбувається корекція відбору енергії з енергоустановок, а Система 3, своєю чергою, має наявні коефіцієнти у всіх колах, що дає можливість сповна оптимізувати систему. Результати досліджень підтвердили, що найефективнішою є Система 3, що, завдяки додатково введеним взаємозв'язкам, які впливають на усі DC-DC перетворювачі, оптимально керує як відбором енергії від усіх джерел, так і іï розподілом по накопичувачах енергії. Саме тому напруга, що прикладається до навантаження має найменший розкид коливань, перехідні процеси струмів акумуляторної батареї та навантаження проходять плавно, а також підтримуються на певному рівні.

\section{Висновки}

Синтез системи енергоформуючого керування вітросонячною енергоустановкою дає змогу одержати регулятори із широкими можливостями для налаштування. Проведені дослідження дали змогу проаналізувати вплив параметрів регуляторів енергоформуючих систем керування (додатково введених взаємозв'язків та демпфувань) та їх поєднання на роботу вітросонячної енергоустановки, а також виокремити найефективніші структури регуляторів.

\section{Список використаних джерел}

1. Півняк Г., Шкрабеиь Ф., Нойбергер Н., Ципленков Д. Основи вітроенергетики: підручник. Дніпро: НГУ, 2015. $335 \mathrm{c}$.

2. Щур В. I. Енергоефективне керування вітроустановками малої потужності для генерування електричної і теплової енергії: автореф. дис. ...канд. тех. наук: спеи 05.09.03. Національний університет «Львівська політехніка». Львів, 2017. 246 с.

3 Климко В. І. Вітросонячні системи електроживлення малопотужних споживачів: автореф. дис. ... канд. тех. наук: спец 05.09.03. Національний університет «Львівська політехніка». Львів, 2016. 209 с.

4. Shchur I., Biletskyi Y. Interconnection and damping assignment passivity-based control of semi-active and active battery/supercapacitor hybrid energy storage systems for stand-alone photovoltaic installations. Proceedings of the 14th International Conference on Advanced Trends in Radioelectronics, Telecommunications and Computer Engineering, TCSET . 2018, Pages 324-329. Vol. 18. pp. 324-329.

5. Щур І. 3., Білецький Ю. О. Енергоформуюче керування нелінійними електромеханічними системами 3 синхронними машинами на постійних магнітах: монографія. Львів: Видавництво Львівської політехніки, 2016.174 с.

6. Shchur I., Klimko V. Feasibility study of the parameters of a hybrid wind-solar system for power supply of an individual object. Elektromehanichni i energozberigayuchi sistemi. 2014. Vol. 2. P. 92-100..

7. Biletskyi Y., Shchur I., Shcherbovskyh S. Mechanical damping in energy-shaping control system of permanent magnet synchronous motor. Proceedings of the 4th Int. Conf, of Young Scientists EPECS-2013. Electronic edition on CD-ROM. Lviv, 2013. pp. 76-77.

8. Ortega R., van der Schaft A. J., Castanos F., Astolfi A. Control by interconnection and standart passivitybased control of port-hamailtonian systems. IEEE Contr. Syst. Tech.. 2008. Vol. 53. No. 11. pp. 2527-2542. 
9. Shchur I., Rusek A., Biletskyi Y. Energy-shaping optimal load control of PMSG in a stand-alone wind turbine as a port-controlled Hamiltonian system. Przeglad elektrotechniczny (Electrical review). 2014. Vol. 5. pp. 50-55.

10. Щур І.З., Білецький Ю.О. Застосування принципів пасивного керування до синхронної машини 3 постійними магнітами як Гамільтонової системи з керованими входами/виходами. Електротехнічні та комп'ютерні системи. Тем. випуск: Проблеми автоматизованого електропривода. Теорія $і$ практика. К.: Техніка, 2011. С. 77-79.

11. Alexandru C., Pozna C. Different tracking strategies for optimizing the energetic efficiency of a photovoltaic system. IEEE International Conference on Automation, Quality and Testing, Robotics (AQTR) (22-25 May 2008, Cluj-Napoca, Romania). 2008. Vol. 3. pp. 434-439.

12. Chong W., Naghavi M., Poh S., Mahlia T., Pan K. Techno-economic analysis of a wind-solar hybrid renewable energy system with rainwater collection feature for urban high-rise application. Applied Energy. 2011. Vol. 88. pp. 4067-4077.

13. Ekren O., Ekren B. Size optimization of a PV/wind hybrid energy conversion system with battery storage using simulated annealing. Applied Energy. 2010. Vol. 87. pp. 592-598.

14. Nowdeh S., Mahdi H. Economic designing of pv/fc/wind hybrid system considering components availability. I. J. Modern Education and Computer Science. 2013. Vol. 7. pp. 69-77.

15. Kuzyk R.-I., Biletskyi Y. Energy-Shaping Control of the Wind-Solar Power Plant with a Hybrid Energy Storage System. Proceedings of the 9th Int. Conf, of Young Scientists EPECS-2019. Electronic edition on CD-ROM. 2019. pp. 84-89.

\section{References}

1. Pivnyak G., Shkrabec' F., Nojberger N., Ciplenkov D.. Fundamentals of wind power. Textbook. Dnipro: NGU, 2015. 335 p.(Ukr).

2. Shchur V. I. Energy efficient control of low power wind turbines for generating electrical and thermal energy: author's abstract of Ph.D. tech. sci. diss.: 05.09.03 / Lviv Polytechnic National University. Lviv, 2017. 246 p. (Ukr).

3 Klimko V. I. Wind-powered power systems for low-power consumers: author's abstract of Ph.D. tech. sci. diss.: 05.09.03 / Lviv Polytechnic National University. Lviv, 2016. 209 p. (Ukr)

4. Shchur I., Biletskyi Y. Interconnection and damping assignment passivity-based control of semi-active and active battery/supercapacitor hybrid energy storage systems for stand-alone photovoltaic installations. Proceedings of the 14th International Conference on Advanced Trends in Radioelectronics, Telecommunications and Computer Engineering, TCSET. 2018, Pages 324-329. Vol 18. pp. 324-329.

5. Shchur I. Z., Biletskyi Y. O. Energy-shaping control of non-linear electromechanical systems with permanent magnet synchronous machines. Monograph. Lviv: Vidavnictvo L'vivs'koi politehniki, 2016. 174 p. (Ukr).

6. Shchur I., Klimko V. Feasibility study of the parameters of a hybrid wind-solar system for power supply of an individual object. Elektromehanichni i energozberigayuchi sistemi. 2014. Vol. 2. P. 92-100.

7. Biletskyi Y., Shchur I., Shcherbovskyh S. Mechanical damping in energy-shaping control system of permanent magnet synchronous motor. Proceedings of the 4th Int. Conf, of Young Scientists EPECS-2013. Electronic edition on CD-ROM. Lviv, 2013. pp. 76-77..

8. Ortega R., van der Schaft A. J., Castanos F., Astolfi A. Control by interconnection and standart passivitybased control of port-hamailtonian systems. IEEE Contr. Syst. Tech.. 2008. Vol. 53 No. 11. pp. 2527-2542..

9. Shchur I., Rusek A., Biletskyi Y. Energy-shaping optimal load control of PMSG in a stand-alone wind turbine as a port-controlled Hamiltonian system. Przeglad elektrotechniczny (Electrical review). 2014. Vol. 5. pp. 50-55.

10. Shchur I., Biletskyi Y. Application of the principles of passive control to a permanent magnet synchronous machine as a Hamiltonian system with controlled inputs/outputs. Electrical and Computer Systems. Themes issue: Automated Electric Drive Problems. Theory and Practice. - K.: Tehnika, 2011. - P. 77-79. (Ukr)

11. Alexandru C., Pozna C. Different tracking strategies for optimizing the energetic efficiency of a photovoltaic system. IEEE International Conference on Automation, Quality and Testing, Robotics (AQTR) (22-25 May 2008, Cluj-Napoca, Romania). 2008. Vol. 3. pp. 434-439.

12. Chong W., Naghavi M., Poh S., Mahlia T., Pan K. Techno-economic analysis of a wind-solar hybrid renewable energy system with rainwater collection feature for urban high-rise application. Applied Energy. 2011. Vol. 88. pp. 4067-4077.

13. Ekren O., Ekren B. Size optimization of a PV/wind hybrid energy conversion system with battery storage using simulated annealing. Applied Energy. 2010. Vol. 87. pp. 592-598.

14. Nowdeh S., Mahdi H. Economic designing of pv/fc/wind hybrid system considering components availability. I. J. Modern Education and Computer Science. 2013. Vol. 7. pp. 69-77. 
15. Kuzyk R.-I., Biletskyi Y. Energy-Shaping Control of the Wind-Solar Power Plant with a Hybrid Energy Storage System. Proceedings of the 9th Int. Conf, of Young Scientists EPECS-2019. Electronic edition on CD-ROM. 2019. pp. 84-89.

\author{
Y. Biletskyi \\ Lviv Polytechnic National University, \\ Department of Electromechatronics and Computerized Electromechanical Systems, \\ yurii.o.biletskyi@1pnu.ua

R.-I. Kuzyk
Lviv Polytechnic National University,
Department of Electromechatronics and Computerized Electromechanical Systems,
kyzukrostuk@gmail.com \\ Y. Lompart \\ Lviv Polytechnic National University, \\ Department of Electromechatronics and Computerized Electromechanical Systems, \\ lompartyurii@gmail.com
}

\title{
SYNTHESIS AND ANALYSIS OF THE ENERGY-SHAPING CONTROL SYSTEMS FOR WIND- SOLAR POWER PLANT WITH HYBRID ENERGY STORAGE SYSTEM
}

(C) Biletskyi Y., Kuzyk R.-I., Lompart Y., 2019

Nowadays, one of the main tasks is the development of alternative energy. Despite the considerable number of advantages, such sources of energy as the sun and wind are not permanent, and since these sources naturally work in "antiphase" it is advisable to use them together. Also, due to their instability, they are typically used with various types of storage systems, in particular hybrid energy storage systems, such as a combination of batteries and supercapacitors, which have better performance. Thus, the object of wind-solar power plant is a complex system that requires a special approach to control. One of the well-known approaches to building control systems for complex objects are energy-based approaches.

This article shows the procedure for synthesize of the universal energy-shaping control system for the wind-solar power plant with hybrid energy storage system with wide range of tuning capabilities. The use of various parameters of the energy-shaping control system, which reflects the introduction of additional interconnections and damping, allows to adjust the energy flow inside closed loop system, and therefore to make customization depending on the desired result. For example, maintaining the voltage provided to the load or the smoothness of the battery current. The influence of possible parameters and their combination on the operation of a closed loop system is analyzed. The four most efficient structures of the energy-shaping control system with different parameter configurations have been synthesized: with natural energy flow, with additional interconnections and damping in the storage subsystems, with interconnections in generation subsystems, and in both types of subsystems. Their comparative studies were carried out, which confirmed the feasibility of introducing additional interconnections in all subsystems, namely: solar power plant, wind power plant, battery and supercapacitor. Such a system is able to provide optimal control of both the extracion of energy from all sources and its distribution across energy storage.

Energy-shaping controls systems of wind-solar power plants, through the introduction of additional interconnections and damping, provide wide customization capabilities, this can be especially useful for complex systems such as wind-solar power plants with hydride energy storage systems, where the coordination of subsystems operation, that meets many the requirements, is needed.

Keywords: control systems, energy-based approaches, energy-shaping control, wind power, solar power, hybrid energy storage. 